\title{
The Risk Assessment on Bamboo Weaving Craftsmen in Rajapolah District Tasikmalaya Regency
}

\author{
Analisis Risiko pada Pengrajin Anyaman Bambu di Kecamatan Rajapolah \\ Kabupaten Tasikmalaya
}

\author{
Isyeu Sriagustini, Teni Supriyani \\ STIKes Respati Tasikmalaya \\ Jl. Singaparna KM. 11, Cikunir, Singaparna District, Tasikmalaya, West Java, 46418 Indonesia
}

\begin{abstract}
Introduction: Tasikmalaya Regency is one of the areas in West Java that has a large industrial potential, especially small and handicraft industries. Every workplace, both formal and informal, has various potential hazards that can affect the health of workers or can cause occupational diseases. As bamboo is sharp, the craftsmen must be very careful in treating bamboo as a woven materialbecause the risk of accidents such as cutting off hands, being punctured by bamboo slats, and the risk of other potential mechanical hazards can occur. The purpose of this study is to analyze the occupational health and safety risks of woven craftsmen in the Rajapolah District, Tasikmalaya Regency. Methods: This study was a descriptive study. 5 Bamboo weaving craftsmen were the subjects of this study. Meanwhile, the objects of this study were the work process and workplace environment. Data collection was carried out by observation and interviews. Data analysis was performed using a semi-quantitative risk analysis method according to AS/NZS 4360: 2004 standard. Results: 23 potential hazards are identified from all stages of the bamboo process, and 23 health and safety risks are identified from all potential hazards, with 1 risk at a lowrisk level, 15 risks at a medium risk level, and7 risks at a highrisk level. Conclusion: There are 7 risks at the high-risk level that must be prioritized for control, originating from the potential hazards of ergonomics and chemicals.
\end{abstract}

Keywords: bamboo woven craftsmen, potential hazards, risk assessment, semi-quantitative

\begin{abstract}
ABSTRAK
Pendahuluan: Kabupaten Tasikmalaya merupakan salah satu daerah di Jawa Barat yang memiliki potensi industri cukup besar, khususnya industri kecil dan kerajinan. Setiap tempat kerja baik formal maupun informal memiliki berbagai potensi bahaya yang dapat mempengaruhi kesehatan tenaga kerja atau dapat menyebabkan timbulnya penyakit akibat kerja. Sembilu dari bambu sifatnya tajam, pengrajin harus sangat hati-hati dalam memperlakukan bambu sebagai bahan anyaman, karena risiko kecelakaan seperti tangan tersayat, tertusuk bilah bambu, dan risiko dari potensi bahaya mekanik lainnya dapat terjadi. Tujuan penelitian ini adalah melakukan analisis risiko keselamatan dan kesehatan kerja pada pengrajin anyaman di Kecamatan Rajapolah Kabupaten Tasikmalaya. Metode: Penelitian ini merupakan penelitian deskriptif. Subjek penelitian adalah pengrajin anyaman bambu sebanyak 5 orang. Objek penelitian adalah proses kerja serta lingkungan tempat kerja. Pengumpulan data dilakukan dengan observasi dan wawancara. Analisis data dilakukan dengan metode analisis risiko semi kuantitatif sesuai dengan standar AS/NZS 4360:2004. Hasil: 23 potensi bahaya teridentifikasi dari seluruh tahapan proses pembuatan anyaman bambu, dan 23 risiko kesehatan dan keselamatan kerja teridentifikasi dari semua potensi bahaya, dengan rincian 1 risiko pada tingkat low-risk, 15 risiko pada tingkat moderate risk dan risiko 7 risiko pada ringkat high-risk. Simpulan: Terdapat 7 risiko pada tingkat high-risk yang harus diprioritaskan untuk pengendalian, berasal dari potensi bahaya ergonomi dan bahaya kimia.
\end{abstract}

Kata kunci: analisis risiko, potensi bahaya, pengrajin anyaman bambu, semi kuantitatif

Corresponding Author:

Isyeu Sriagustini

Email: isyeutnt@gmail.com

Telephone: +628122290361

\section{INTRODUCTION}

The number of work accidents is still a problem that must be controlled. Based on the Employment Health Social Security Administering Bodies, the number of accidents in Indonesia in 2017 was 123,041 cases and increased in 2018 to 173,105 
cases, before decreasing again in 2019 to 77,295 cases. However, even though it has decreased, there are some cases of accidents that must be given attention, particularly in relation to health efforts and accidents at the workplace. These accidents are still dominated by minor accidents in a work environment with particular characteristics of factory (Social Security Administrative Body, 2019).

Every workplace, both formal and informal, has various potential hazards that can affect workforce safety or can cause occupational disease risks. Tasikmalaya Regency is an area in West Java that has quite a large industrial potential, especially small and handicraft industries, which can absorb a lot of workers. Rajapolah District, specifically, is one of the centers of the handicraft industry in Tasikmalaya. In 2019 there were 1,824 (47.7\%) small weaving industries in Rajapolah District with 4,256 craftsmen (Central Bureau of Statistics of Tasikmalaya Regency, 2019). The high number of industries not only provides welfare for life, but also presents adverse impacts on the health of workers. The threat comes from an imbalance in the interaction between work capacity, workload, and the additional burden experienced by the workers (Suma'mur, 2009; Ramli, 2010b).

Woven is another name for pottery, which is made from the arrangement of material blades whose name depends on the material used. There are three types of materials used as materials for the superior handicraft products in Rajapolah District, namely: bamboo, mending, and pandan. When viewed from its characteristics, bamboo has a potential hazard with a higher risk of accidents than pandan and mendong. Blades of split bamboo ("hinis") are sharp and in some cases can be used as cutting tools, such as cutting the placenta or circumcision in ancient times (Prabawati, 2016). Therefore, the craftsmen must be very careful in treating bamboo as a woven material because the risk of accidents such as cutting off hands whenpuncturing bamboo blades, and being exposed to mechanical hazards can occur. In addition, other potential hazards from the work process, tools and work environment that have not been identified and recorded can be health risks and work accidents for woven bamboo craftsmen.

Even the smallest potential hazards of occupational accidents and health risks must be controlled because occupational health efforts absolutely must be carried out in both formal and informal industries as mandated in Law on Health No36 Year 2009 (President of the Republic of
Indonesia, 2009). The opportunities for the informal sector, especially the bamboo weaving industry to absorb labor, are getting higher, but unfortunately it is not accompanied by attention to the aspects of occupational health and safety. Therefore, as the first step in carrying out occupational health efforts for woven bamboo craftsmen, it is necessary to complete the data regarding the potential hazards that may be exposed as well as the occupational healthand safety risks of woven bamboo craftsmen to make a hazard risk control plan in the workplace. The purpose of this study is to identify hazards, conduct risk assessments, and provide recommendations for risk control at the stages of making bamboo weaving crafts.

\section{METHODS}

This type of research was a descriptive study. The research was carried out in one of the small and medium industries of woven bamboo handicrafts that supply handicrafts at the Rajapolah District Craft Center. The research was conducted in July 2020. This research has been accepted by the Health Research Ethics Committee STIKes BTH Tasikmalaya, with a certificate number $005 /$ kepkbth/II/2020.

The research subjects were all craftsmen at each stage of the process of making woven bamboo crafts, which accounted for 5 craftsmen. The objects under the study were all work processes and work environment. There were 4 stages of the bamboo weaving process. Sampling was carried out by total sampling technique, namely all craftsmen, work processes, and work environments at each stage of the process of making bamboo weaving crafts.

Table 1. Scale of Likelihood

\begin{tabular}{|c|c|c|}
\hline Value & Category & Description \\
\hline 5 & Almost Certain & $\begin{array}{l}\text { It is likely / almost } \\
\text { certainly will happen to all } \\
\text { occasions }\end{array}$ \\
\hline 4 & Likely & $\begin{array}{l}\text { Maybe or not something } \\
\text { strange will happen }(50 \text { - } \\
50)\end{array}$ \\
\hline 3 & Possible & $\begin{array}{l}\text { It is unlikely that something } \\
\text { will happen }\end{array}$ \\
\hline 2 & Unlikely & $\begin{array}{l}\text { Unprecedented after years } \\
\text { of exposure to the hazard / } \\
\text { very unlikely to happen) }\end{array}$ \\
\hline 1 & Rare & $\begin{array}{l}\text { It has not happened before } \\
\text { anywhere / it is impossible } \\
\text { to happen }\end{array}$ \\
\hline
\end{tabular}


The variables studied were potential hazards, occupational health, and safety risks, as well as controls that had been carried out at each stage of the process of making bamboo weaving crafts. Data collection was carried out by means of observation and interviews. Observations were made to determine the stages of the process of making bamboo woven crafts, tools used, and the workplace environment, while the interviews were done to gather information about health risks and work accidents that may arise during the work process.

Table 2. Scale of Consequence

\begin{tabular}{ccl}
\hline Value & Category & \multicolumn{1}{c}{ Description } \\
\hline 5 & Catastrophic & $\begin{array}{l}\text { Fatal more than 1 person, } \\
\text { very large losses and very } \\
\text { wide impacts, cessation of } \\
\text { all activities (catastrophe) } \\
\text { Severe injury }>\text { 1person, } \\
\text { big loss, disruption of } \\
\text { production (disaster) } \\
\text { Moderate injury, medical } \\
\text { treatment, major financial } \\
\text { loss (very serious) } \\
\text { Minor injury minimal } \\
\text { financial loss (medical } \\
\text { treatment) } \\
\text { No injuries, little financial } \\
\text { loss (P3K) }\end{array}$ \\
\hline
\end{tabular}

Tabel 3. Scale of Risk Level

\begin{tabular}{|c|c|c|}
\hline Value & Risk Level & Description \\
\hline $16-25$ & $\begin{array}{l}\text { Extreme risk } \\
\text { (E) }\end{array}$ & $\begin{array}{l}\text { Extreme risk, carries out a } \\
\text { Root Cause Analysis (RCA) } \\
\text { for a maximum of } 45 \text { days, } \\
\text { requires immediate actions, } \\
\text { attention goes to the Director } \\
\text { of the hospital }\end{array}$ \\
\hline $12-15$ & High-risk (H) & $\begin{array}{l}\text { High-risk, carries out RCA } \\
\text { no later than } 45 \text { days, review } \\
\text { in detail and need immediate } \\
\text { actions, requires top } \\
\text { management action/Quality } \\
\text { Team Leader }\end{array}$ \\
\hline $7-10$ & $\begin{array}{l}\text { Moderate risk } \\
\text { (M) }\end{array}$ & $\begin{array}{l}\text { The risk is under simple } \\
\text { investigation for a maximum } \\
\text { of } 2 \text { weeks. The clinical } \\
\text { manager/leadership should } \\
\text { assess the impact on hazards } \\
\text { and manage risks (responsible } \\
\text { doctor) }\end{array}$ \\
\hline $1-5$ & Low-risk (L) & $\begin{array}{l}\text { A simple investigation is } \\
\text { carried out for a maximum } \\
\text { of } 1 \text { week, completed with a } \\
\text { routine procedure (SPO) }\end{array}$ \\
\hline
\end{tabular}

Data processing was carried out by identifying potential health, and safety hazards and risks at all stages of the bamboo woven making activity, by completing the Job Hazard Analysis (JHA) table's (Stamatis, 2014). Data analysis was carried out using a risk analysis approach using semi-quantitative techniques (Ramli, 2010b). At this stage, a risk assessment was carried out on all potential hazards and risks that had been identified by determining the magnitude of the risks related to the likelihood, and the magnitude of the consequences using the risk assessment guidelines from the AS risk management standard (Australian Standard/New Zealand Standards, 2004).

The final stage of data analysis was conducted by determining the level of risks by calculating the multiplication between the likelihood and consequence value. The results of the calculation were then interpreted with a scale of risk levels, shown in Table 3.

\section{RESULTS}

\section{The Process of Making Bamboo Woven}

The activity of making woven bamboo crafts is generally divided into two stages, namely: the

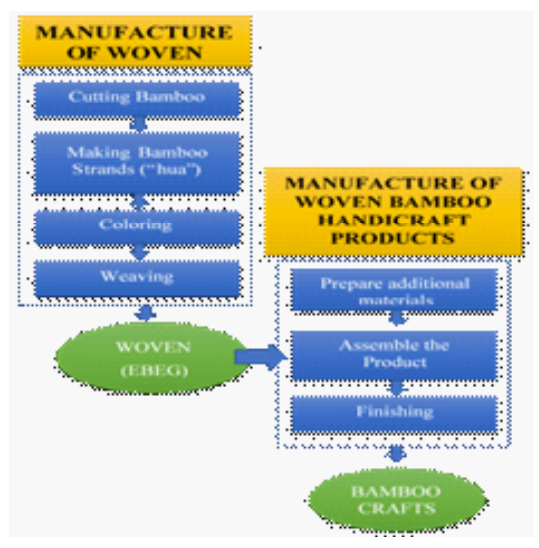

Figure 1. Stages of Making Woven Bamboo Crafts

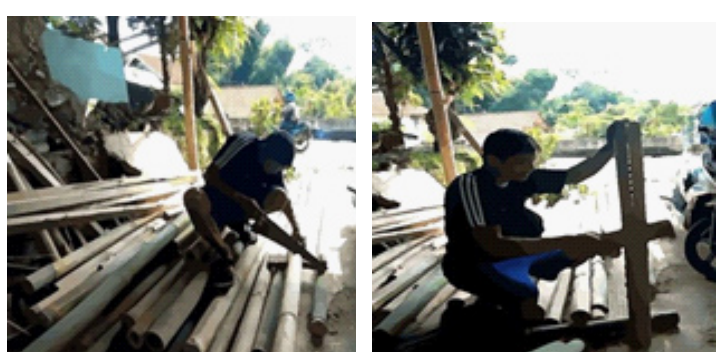

Figure 2. Cutting Bamboo 
manufacture of woven materials and the manufacture of woven bamboo handicraft products. The making of wicker is the initial stage of the whole making process of woven bamboo crafts, which is the basic material for making crafts.

The stage of the woven-making process starts from the bamboo cutting stage to the wicker-making stage. At this stage there are four work activities, namely: cutting bamboo, making bamboo strands called "hua", coloring and weaving.

\section{Cutting Bamboo}

At this stage, the craftsmen divide the bamboo logs into bamboo pieces using a saw. They divide the bamboo pieces into bamboo slats using a machete. The work is done in a squatting position.

\section{Making Bamboo Strands ("hua”)}

The bamboo blade is cleaned using a sharp knife. The craftsmen perform this activity by sitting on the floor with his body and neck bent. The craftsmen do this activity over and over again with the left-hand holding the bamboo strands, and the
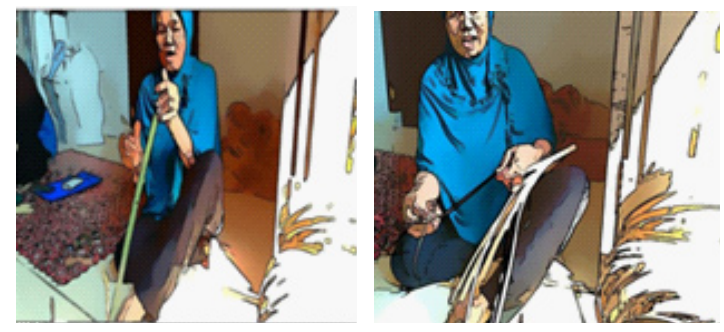

Figure 3. Making Bamboo Strands ("hua")

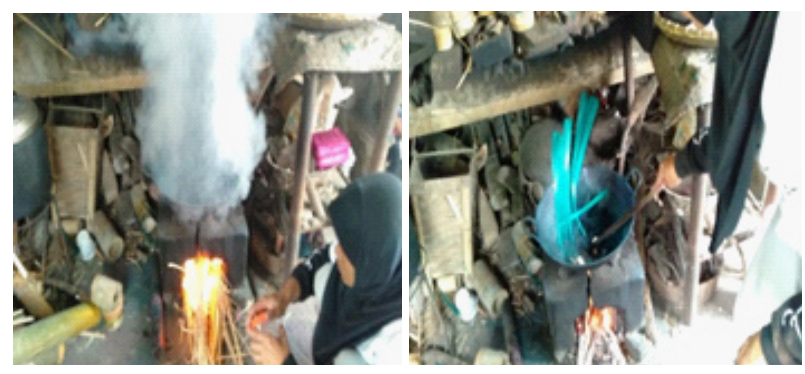

Figure 4. Coloring

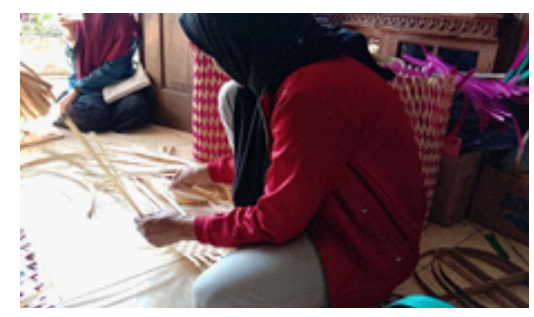

Figure 5. Weaving right-hand holding the "raut" knife until the bamboo hairs (hinis) disappear.

\section{Coloring}

The craftsmen give color to the bamboo strands by preparing the color material. It is done by making boiled water mixed with the desired color and when ready, the bamboo strands are inserted one by one into the colored boiled water to get the desired color.

\section{Weaving}

The craftsmen join the bamboo strands with each other to make a woven bamboo called "ebeg". The craftsmen skilfully use their hands repeatedly to connect one bamboo strand to another. This work is done by sitting on the floor for some time.

\section{Risk Assessment}

Risk Assessment is carried out in three stages, namely: identification of potential hazards and risks, risk analysis, and risk evaluation (Australian Standard/New Zealand Standards, 2004). The results of risk assessment at each stage of the woven bamboo making process can be seen inT 4 . Based on Table 4, it is shown that there are 22 identified potential hazards, namely: 2 types of physical hazards, 5 types of chemical hazards, 6 types of ergonomic hazards, and 9 types of mechanical hazards.

Moreover, there are 22 occupational health and safety risks at the weaving stage. Specifically1 risk has a value of 1-5 (low-risk), 15 risks have a value of 7-10 (moderate risk), and 6 risks have a value of 12-15 (High-risk).

\section{Risk Control}

There is not much risk control in the process of making bamboo woven. Existing controls only use simple equipment such as a black duct tape which is attached to the hand or finger to protect the hand from being cut caused by bamboo material, the use of a raut knife, and use of a nose cover with the veil to avoid smoke from the combustion process. Sometimes craftsmen use gloves to protect their hands from bamboo material. Based on the results of the risk assessment, the recommended controls can be seen in Table 5 .

Based on the risk results, it is known that 23 potential hazards are identified from all stages of the bamboo process, and 23 health and safety risks are identified from all potential hazards, Specifically, 1 
risk is at a low-risk level, 15 risks are at a medium risk level, and 7 risks are at a high-risk level. There are 7 risks at the high-risk level that must be prioritized for control, originating from the potential hazards of ergonomics and chemicals.

Risk control recommendations for ergonomic hazards are eliminating awkward work positions and repetitive hand movements, changing a working position from sitting on the floor to sitting on an ergonomically suitable table and chair, providing suitable work desks and chairs, receving risk education from awkward positions during work, and relaxing and stretching every 2 hours.

Meanwhile, chemical hazard control is carried out by eliminating the source of the hazard, namely the use of naphthol dyes, dye substitution with natural dyes, education about the risks of using dyes, and compliance with wearing masks,

Table 4. Results of Occupational Health and Safety Risk Assessment in the Bamboo Woven Process

\begin{tabular}{|c|c|c|c|c|c|c|}
\hline \multirow{2}{*}{ Work Process } & \multicolumn{2}{|c|}{ Hazard and Risk Identification } & \multicolumn{3}{|c|}{ Risk Analysis } & \multirow{2}{*}{$\begin{array}{l}\text { R i s k } \\
\text { Evaluation } \\
\text { Risk level }\end{array}$} \\
\hline & Hazard & Risk & Hazard & Risk & $\begin{array}{l}\text { Risk value } \\
(\mathrm{R}=\mathrm{LxR})\end{array}$ & \\
\hline \multirow{8}{*}{$\begin{array}{l}\text { Cutting } \\
\text { Bamboo }\end{array}$} & Bamboo dust & $\begin{array}{l}\text { Respiratory disorders, Skin } \\
\text { irritation (itchy) }\end{array}$ & 4 & 2 & 8 & Moderate \\
\hline & Noise from manual saw & Hearing disorders & 3 & 3 & 9 & Moderate \\
\hline & Vibration & Hand-Arm Vibration & 2 & 3 & 6 & Low \\
\hline & Manual Saw & Cut wounds & 3 & 3 & 9 & Moderate \\
\hline & Machete & Cut wounds & 3 & 3 & 9 & Moderate \\
\hline & Pieces of bamboo "Hinis" & Incised wounds & 5 & 2 & 10 & Moderate \\
\hline & Bamboo blade "Hinis" & Incised wounds & 5 & 2 & 10 & Moderate \\
\hline & $\begin{array}{l}\text { Squatting position: body } \\
\text { and neck bent }\end{array}$ & $\begin{array}{l}\text { Discharge of skeletal muscle pain } \\
\text { (pain/stiffness in the back and } \\
\text { neck) }\end{array}$ & 4 & 3 & 12 & High \\
\hline \multirow{5}{*}{$\begin{array}{c}\text { Making } \\
\text { Bamboo } \\
\text { Strands ("hua") }\end{array}$} & Bamboo dust & $\begin{array}{l}\text { Respiratory disorders, skin } \\
\text { irritation (itchy) }\end{array}$ & 5 & 2 & 10 & Moderate \\
\hline & Raut knife & Incised wounds & 5 & 2 & 10 & Moderate \\
\hline & Bamboo strands "Hinis" & Incised wounds & 5 & 2 & 10 & Moderate \\
\hline & $\begin{array}{l}\text { Sitting position on the floor. } \\
\text { Body: back and neck bent }\end{array}$ & $\begin{array}{l}\text { Discharge of skeletal muscle (pain } \\
\text { / stiffness in the back and neck) }\end{array}$ & 4 & 3 & 12 & High \\
\hline & Repetitive hand movements & $\begin{array}{l}\text { Discharge of skeletal skeletal } \\
\text { muscle (pain/stiffness in the } \\
\text { hands) }\end{array}$ & 4 & 3 & 12 & High \\
\hline \multirow{7}{*}{ Coloring } & $\begin{array}{l}\text { Synthetic dyes, namely } \\
\text { naphthol or other dyes that } \\
\text { are classified as base paints }\end{array}$ & $\begin{array}{l}\text { Respiratory tract irritation, eye } \\
\text { irritation, skin irritation }\end{array}$ & 3 & 4 & 12 & High \\
\hline & $\begin{array}{l}\text { The hot temperature of the } \\
\text { combustion process }\end{array}$ & Heat stress & 3 & 2 & 6 & Low \\
\hline & Hot water & Hot water splash burns & 3 & 3 & 9 & Moderate \\
\hline & Hot equipment & Burns exposed to hot equipment & 3 & 3 & 9 & Moderate \\
\hline & Burning smoke & Respiratory disorders & 3 & 3 & 9 & Moderate \\
\hline & $\begin{array}{l}\text { Fire in the combustion } \\
\text { process }\end{array}$ & Fire & 2 & 5 & 5 & Moderate \\
\hline & $\begin{array}{l}\text { Standing position with body } \\
\text { and neck bent }\end{array}$ & $\begin{array}{l}\text { Discharge of skeletal muscle (pain/ } \\
\text { stiffness in the back and neck) }\end{array}$ & 4 & 3 & 12 & High \\
\hline \multirow{3}{*}{ Weaving } & Bamboo strands "Hinis" & Incised wounds & 5 & 2 & 10 & Moderate \\
\hline & $\begin{array}{l}\text { Sitting position on the floor. } \\
\text { Body: back and neck bent }\end{array}$ & $\begin{array}{l}\text { Discharge of skeletal muscle (pain/ } \\
\text { stiffness in the back and neck) }\end{array}$ & 4 & 3 & 12 & High \\
\hline & Repetitive hand movements & $\begin{array}{l}\text { Discharge of skeletal muscle } \\
\text { (pain/stiffness in the hands) }\end{array}$ & 4 & 3 & 12 & High \\
\hline
\end{tabular}


Table 5. Recommendations on Risk Control

\begin{tabular}{|c|c|c|c|c|c|}
\hline Risk Level & Hazard Type & Hazard & Risk & Risk Control & Control Recommendations \\
\hline \multirow[t]{2}{*}{ High-risk } & Ergonomics & $\begin{array}{l}\text { S q u a t t i n g, } \\
\text { Sitting, standing } \\
\text { position: body } \\
\text { and neck bent }\end{array}$ & $\begin{array}{l}\text { Discharge of } \\
\text { skeletal muscle } \\
\text { (pain/stiffness } \\
\text { in the back and } \\
\text { neck) }\end{array}$ & No control & $\begin{array}{l}\text { Elimination: eliminating awkward } \\
\text { work positions and repetitive hand } \\
\text { movements } \\
\text { Substitution: changing a work position } \\
\text { from sitting on the floor to sitting on } \\
\text { an ergonomically suitable table and } \\
\text { chair } \\
\text { Engineering: providing appropriate } \\
\text { work desks and chairs } \\
\text { Administrative: giving risk education } \\
\text { about awkward positions during work; } \\
\text { relaxation and stretch every } 2 \text { hours. } \\
\text { Personal protective equipment: - }\end{array}$ \\
\hline & Chemical & $\begin{array}{l}\text { Synthetic dyes: } \\
\text { Naphthol }\end{array}$ & $\begin{array}{l}\text { Respiratory tract } \\
\text { irritation, eye } \\
\text { irritation, skin } \\
\text { irritation }\end{array}$ & No control & $\begin{array}{l}\text { Elimination: eliminating the source } \\
\text { of danger, namely the use of naphthol } \\
\text { coloring agents } \\
\text { Subtitution: substituting the artifial } \\
\text { dyes with natural dyes } \\
\text { Engineering: - } \\
\text { Administrative: giving education } \\
\text { about the risks of using dyes } \\
\text { Personal protective equipment: } \\
\text { Wearinga mask, gloves, and glasses }\end{array}$ \\
\hline \multirow{3}{*}{ Moderate Risk } & \multirow{3}{*}{ Mechanical } & $\begin{array}{l}\text { Use of tools such } \\
\text { as saws, bedogs } \\
\text { or machetes, } \\
\text { raut knives }\end{array}$ & Cut wounds & $\begin{array}{l}\text { Sometimes use } \\
\text { gloves or use } \\
\text { black duct tape } \\
\text { on their fingger }\end{array}$ & $\begin{array}{l}\text { Elimination: eliminating the use } \\
\text { of tools such as saws, bedogs or } \\
\text { machetes, raut knives } \\
\text { Substitution: - } \\
\text { Engineering: - } \\
\text { Administrative: increasing the } \\
\text { understanding of the risks of using } \\
\text { tools such as saws, bedogs or } \\
\text { machetes, and raut knives } \\
\text { Personal protective equipment: always } \\
\text { wearing gloves }\end{array}$ \\
\hline & & $\begin{array}{l}\text { Hot water and } \\
\text { hot equipment }\end{array}$ & $\begin{array}{l}\text { Hot water splash } \\
\text { burns and Burns } \\
\text { exposed to hot } \\
\text { equipment }\end{array}$ & No control & $\begin{array}{l}\text { Elimination: eliminating the work } \\
\text { process of dyeing and permeating so } \\
\text { that no tools or materials are hot } \\
\text { Substitution: replacing tools with } \\
\text { heat-resistant equipment } \\
\text { Engineering: - } \\
\text { Administrative: providing an } \\
\text { understanding of the danger of using } \\
\text { hot equipment and materials } \\
\text { Personal protective equipment: } \\
\text { wearing gloves, apron }\end{array}$ \\
\hline & & $\begin{array}{l}\text { The bamboo } \\
\mathrm{m} \text { a } \mathrm{t} \text { e } \mathrm{r} \text { i a } 1 \\
\text { itself: pieces } \\
\text { of bamboo and } \\
\text { bamboo blades }\end{array}$ & Incised wounds & $\begin{array}{l}\text { Som etimes } \\
\text { use gloves or } \\
\text { use black duct } \\
\text { tape on their } \\
\text { finggers }\end{array}$ & $\begin{array}{l}\text { Elimination: removing bamboo } \\
\text { material } \\
\text { Substitution: replacing bamboo with } \\
\text { a safer one, for example pandanus or } \\
\text { mendong } \\
\text { Engineering: - } \\
\text { Administrative: understanding more } \\
\text { about the boundaries of the bamboo } \\
\text { material and the possible risks } \\
\text { involved } \\
\text { Personal protective equipment:always } \\
\text { wearing gloves }\end{array}$ \\
\hline
\end{tabular}




\section{Lanjutan Table 5}

\begin{tabular}{|c|c|c|c|c|c|}
\hline Risk Level & Hazard Type & Hazard & Risk & Risk Control & Control Recommendations \\
\hline \multirow{5}{*}{ Moderate Risk } & \multirow[t]{2}{*}{ Chemical } & $\begin{array}{l}\text { B a m b o o } \\
\text { dust }\end{array}$ & $\begin{array}{l}\text { Respiratory } \\
\text { dis orders, } \\
\text { skinirritation } \\
\text { (itchy) }\end{array}$ & No control & $\begin{array}{l}\text { Elimination: removing bamboo material and } \\
\text { cutting bamboo } \\
\text { Substitution: replacing bamboo with a safer one, } \\
\text { for example pandanus or mendong } \\
\text { Engineering: cutting bamboo or using bamboo } \\
\text { when it is wet } \\
\text { Administrative: understanding more about the } \\
\text { boundaries of the bamboo material and the } \\
\text { possible risks involved } \\
\text { Personal protective equipment: Wearing a mask, } \\
\text { cover all, or wearing a cloth which can cover the } \\
\text { body }\end{array}$ \\
\hline & & $\begin{array}{l}\text { Fire in the } \\
\text { combustion } \\
\text { process }\end{array}$ & Fire & No control & $\begin{array}{l}\text { Elimination: eliminating the combustion process } \\
\text { Substitution: using a stove with good control of } \\
\text { flame } \\
\text { Engineering: Providing fire extinguishers and } \\
\text { rearranging the placement of materials and } \\
\text { incinerators } \\
\text { Administrative: understanding the fire risks } \\
\text { Personal protective equipment: providing light } \\
\text { fire extinguishers }\end{array}$ \\
\hline & \multirow{3}{*}{ Physical } & $\begin{array}{l}\text { B u r n ing } \\
\text { Smoke }\end{array}$ & $\begin{array}{l}\text { Respiratory } \\
\text { disorders }\end{array}$ & $\begin{array}{l}\text { Use a veil } \\
\text { to cover the } \\
\text { nose from the } \\
\text { smoke }\end{array}$ & $\begin{array}{l}\text { Elimination: eliminating the combustion process } \\
\text { Substitution: replacing the furnace whit a stove } \\
\text { Engineering: - } \\
\text { Administrative: understanding the smoke risks } \\
\text { Personal protective equipment: Wearing a mask }\end{array}$ \\
\hline & & Noise & $\begin{array}{l}\mathrm{H} \text { e a } \mathrm{r} \text { i } \mathrm{n} g \\
\text { disorders }\end{array}$ & No control & $\begin{array}{l}\text { Elimination: eliminating the use of saws or } \\
\text { bamboo cutting process } \\
\text { Substitution: Replacing the saws so as not to } \\
\text { cause noise } \\
\text { Engineering: - } \\
\text { Administrative: understanding the dangerof noise } \\
\text { and its control. } \\
\text { Personal protective equipment: Wearing earplugs } \\
\text { or ear muffs to reduce noise levels if they exceed } \\
\text { the Threshold Limit Values (TLV). }\end{array}$ \\
\hline & & Vibration & $\begin{array}{l}\text { Hand-Arm } \\
\text { Vibration }\end{array}$ & No control & $\begin{array}{l}\text { Elimination: eliminating the use of saws or } \\
\text { bamboo cutting process } \\
\text { Substitution: Replacing the saws so as not to } \\
\text { cause vibration } \\
\text { Engineering: reducing vibration effects by } \\
\text { dampening the vibrations } \\
\text { Administrative: Using vibrating tools no more } \\
\text { than } 2 \text { hours; understanding the danger of } \\
\text { vibration and its control } \\
\text { Personal protective equipment: Wearing multi- } \\
\text { layer and chewy gloves (rubber, foam rubber, } \\
\text { foam plastic, wool) or wearing vibration-proof } \\
\text { gloves whenever possible }\end{array}$ \\
\hline Low-risk & Physical & $\begin{array}{l}\text { The hot } \\
\text { temperature } \\
\text { of the } \\
\text { combustion } \\
\text { process }\end{array}$ & heat stress & No control & $\begin{array}{l}\text { Elimination: eliminating the heat source } \\
\text { Substitution: replacing the process that is the } \\
\text { source of heat e.g. replacing a hot furnace with } \\
\text { a gas stove } \\
\text { Engineering: placing a heat source in an open area } \\
\text { and sufficiently ventilated room will be able to } \\
\text { reduce complaints of fatigue and fatigue while } \\
\text { working. } \\
\text { Administrative: understanding the danger of hot } \\
\text { temperature and its control. } \\
\text { Personal protective equipment: wearing a hat } \\
\text { when doing the drying process to avoid the } \\
\text { sunlight }\end{array}$ \\
\hline
\end{tabular}


gloves and glasses while working. Risk control recommendations for other hazards can be seen in Table 5.

\section{DISCUSSION}

\section{Bamboo Woven Process}

\section{Cutting Bamboo}

In the bamboo cutting process, there is an activity of cutting bamboo logs into bamboo parts as needed. This activity is also carried out under slightly different names and terms in several places where bamboo weaving is made. For example, in Asriyati's (2019) observation results in the process of making lambar bamboo, there are stages called peeling and splitting bamboo. The goal is to cut the bamboo into the desired part, but previously the green skin of the bamboo has been eroded. Likewise, Murti's (2018) observation shows that there is a similar process, namely the process of cutting bamboo into bamboo parts as needed.

The tools used for the cutting process are the same tools, namely manual saws. The working position in the cutting process is not described in more detail in the two observations.

\section{Making Bamboo Strands ("hua")}

The next process is the making of bamboo strands. The activity at this stage is dividing bamboo into several bamboo strands. The craftsmen use a knife to complete this stage. In Asriyati's (2019) observation, this stage is called the stage of making irritants. The craftsmen cut bamboo using a knife. This is different from Murti's (2018) observation stating that in this process the craftsmens use a serkel machine to make bamboo strands, and this process is still included in the bamboo cutting stage. No explanation for the work potitions of craftsmen when carrying out activities at that stage.

\section{Coloring}

When the crafstmen need a colored woven result, the craftsmen will go through the process of dyeing bamboo strands. The dye used is naphtol. The results of observations conducted by Asriyati (2019) does not find the coloring process. Bamboo strands are immediately dried in the sun to reduce the air content. Meanwhile, the results of observations made by Murti (2018) show that there is a coloring process after the drying process. The coloring activity is carried out in the same way, by dipping the bamboo strands in the boiling water that has been filled with the desired color. The coloring agent used is hydrogen feroxide $\left(\mathrm{H}_{2} \mathrm{O}_{2}\right)$. The work position of the craftsman when doing activities is not described in detail as in the two previous stages.

\section{Weaving}

The last process is weaving. The craftsmen unite the bamboo strands in a pattern so that they become a woven fabric, which is the basis for making crafts. The results of observations made by Asriyati (2019) also state that the process of weaving is the final part. The activities carried out are almost the same; the difference is that there is a woven base as a tool to facilitate the manufacture of weaving. Murti's (2018) observation results also show a same finding, suggesting that the weaving process is the final stage before making handicraft products, and the activities carried out are the same. The work position of the craftsman when doing this activity is not described in detail as in the 3 previous stages.

\section{Hazardand Risk Identification}

\section{Mechanical hazards}

The most identified potential hazards are mechanical hazards. Potential mechanical hazards are factors that come from moving objects, sharp objects, large and heavy $\mathrm{r}$ that can pose a risk to workers such as cuts, punctures, pinches, squeezes, cuts, bumps, and so on (Ramli, 2010b). Mechanical hazards are included in the category of hazards that pose an immediate risk to safety (International Labor Organization, 2013).

The use of tools such as saws, machetes, raut knives, in the process of making bamboo woven is a type of mechanical hazard. The use of these tools can create the risk of cut wounds and incised wounds. The same thing happens to the manufacture of furniture. The use of saws in the furniture industry in the wood cutting can be a potential source of mechanical hazards. The risk of being exposed to saw blades and splinters from sawed wood, and being punctured by the sharp texture of wood can occur (Fani, 2013). A cut wound occurs when the wound is regular, is deep and is bleeding profusely when a blood vessel is cut. Therefore, a cut wound requires emergency medical assistance. Incised wounds occur when the wound is shallow and short, 
so treatment with medical bandages is sufficient (Muhammad, 2015; Widyawati, 2019).

The use of hot equipment is also a mechanical hazard that can be identified in the bamboo woven process. If such hot equipment comes into contact with the body, it can cause burns to the affected body. Burns are injuries to body tissues as a result of touching or being exposed to heat from fire, steam, liquids and other hot objects. The pain from the burn is usually very severe. However, minor burns can be treated by the individuals themselves, whereas if a more serious burn can threaten people's safety, they should get emergency medical assistance (Santosa, 2019).

Bamboo material, whether in the form of pieces of bamboo, bamboo blades or bamboo strands are included as mechanical hazards. The source of the danger comes from the sharp material of the bamboo itself and the part of the bamboo which is called "hinis". The risks that might occur are being punctured by material bamboo and being incised by parts of the bamboo which is called "hinis". The impact that can occur is getting punctured and incised. Puncture wounds are usually very deep and cause damage to the tissue inside (Widyawati, 2019). However, the incidence of being punctured with pieces, blades and strands of bamboo hardly occurs, so punctured wounds could be avoided. Punctured wounds usually occur because of the bamboo splinters on the bamboo material. Due to their small size, punctured wounds and incisions are not very serious, and only require self-care.

\section{Ergonomic Hazards}

Another type of potential hazard identified in addition to mechanical hazards are ergonomic hazards. An ergonomic hazard is a factor that can affect the labor activities caused by mismatches between work facilities, including work methods, work equipment and workload (Ministry of Manpower of Republic of Indonesia, 2018). Ergonomic hazards are included in the category of hazards that pose a risk of long-term impacts on health (International Labor Organization, 2013).

Jalajuwita and Paskarini (2015) research shows that there is a welding work that is done by squatting and alternating in awkward positions. In their study, the measurement of ergonomic risk is carried out using the Rapid Entire Body Assessment (REBA) method and the results show that the REBA score is in the high-risk category range, causing musculoskeletal complaints. So, when testing the relationship between the work position and musculoskeletal complaints on welding workers, it shows a significant relationship.

Awkward positions, namely sitting on the floor with the back and head bent, standing with your body and neck bent, and using your hands repeatedly, are all the potential hazards identified in the bamboo weaving process. An awkward posture or unnatural work posture is a posture that causes a position to move away from its natural position, for example, the hands which keeps raised, the back position which is too high, the head which keeps raised, and so on. The farther the body part from the center of the body, the higher the musculoskeletal complaints. This becomes a problem when workers working on their duties maintain an uncomfortable position for a long time (Tarwaka, 2010). In almost all stages of making bamboo woven, craftsmen work in an unnatural way of working, including sitting on the floor with their back and neck bent. If this situation continues, it will result in complaints of skeletal muscle, especially if it is done for a long time. For example, batik works which are done in a sitting posture, which is and not ergonomic, within 8 hours and more can cause neck pain (Yani, 2020).

\section{Chemical Hazards}

Chemical hazards are one of the factors that can affect the labor activities caused by the use of chemicals, and their derivatives at the workplace. Checmical hazards can cause diseases in the workforce, originating from chemical contaminants in the air in the form of gases, vapors, and particulates (Ministry of Manpower of Republic of Indonesia, 2018). In this study, dust generated in the cutting process is identified as a chemical hazard. The biggest health risk comes from fine dust which can be inhaled by craftsmen and then enter and damage the craftsmen's lungs. Furthermore, bamboo dust can induce an allergic response. The main allergic response to inhalation is bronchoconstriction, which is triggered by a reaction between antigen and persistent antibodies. The results of the study conclude that dust levels are correlated with impaired lung function $(\mathrm{p}<0.05)$. The value of dust content in wood cutting is 0.5985 $\mathrm{mg} / \mathrm{m} 3$, in the engraving part is $1.7432 \mathrm{mg} / \mathrm{m} 3$, and in the finishing part is $8.8426 \mathrm{mg} / \mathrm{m} 3$. The dust content in the engraving and finishing sections exceeds TLV (1.00 mg / m3). Moreover, the results of pulmonary function examination show that at 
most 72 respondents (75\%) experience pulmonary obstruction, which is an inflammatory lung disease that develops in the long-term (Ma'rufi, 2017).

In Ardam's (2015) research, it is shown that workers overpower plan have exposure to dust during their work, which comes from the process of making machines with levels that are still below TLV, namely $1.34 \mathrm{mg} / \mathrm{m} 3$ and $5.35 \mathrm{mg} / \mathrm{m} 3$. The results of the analysis show that the higher the exposure to dust in the work environment, the higher the probability of disease disorder. This can be seen in the $1.34 \mathrm{mg} / \mathrm{m} 3$ dust exposure there are still workers who work with normal lung function while in the $5.35 \mathrm{mg} / \mathrm{m} 3$ dust exposure all workers have lung function disorders. In the process of making bamboo wovens that have high exposure to bamboo dust is the bamboo cutting process where during the cutting some of the bamboo dust flies. As for other processes, only a small portion of the bamboo dust is present. However, measurements of dust levels have not been carried out, so it is necessary to measure both the level and the effect of dust exposure.

In addition, bamboo dust can also cause reactions on the skin in the form of itching if the dust is exposed to any part of the body. The itching comes from the part of the bamboo hair which is also cut and becomes bamboo dust. In general, bamboo has hairs called "lugut", which can make the skin itchy or "merang". When the hair gets into the skin, it is recommended that people do not scratch it because it will itch even more. The use of hair or powder can be an option to relieve itching and irritation of the hair caused by bamboo (Setiadi, 2009).

In the process of making bamboo woven, there are stages where chemicals in the form of dyes are applied. The dyes used are synthetic dyes, namely naphthol or other dyes that are classified as basic dyes. Naphthol is a textile substance that can be used to dye quickly and has a strong color. Naphthol is used with diazonium salts to dye bamboo strands. The health risks of using naphtol are inhalation, ingestion and contact with skin and eyes. If inhaled, it can cause airway irritation, coughing and shortness of breath. If swallowed in high doses, it can cause stomach pain, vomiting, sweating, lower blood pressure, anemia, convulsions, and death. Repeated skin exposure even causes skin dermatitis. In addition, it can cause eye irritation, redness, pain and damage to the cornea (National Poisoning Information Centre, 2011).

Other potential hazards, included in the type of chemical hazards, are smoke and fire in the combustion process. Fire occurs because of a chemical process between fuel vapor with oxygen and heat assistance. Fire can be a source of disaster, especially in the event of a fire. A Fire is fire that is out of control, and cause harms to humans, property and the environment. The high heat can cause burns, both minor burns and serious injuries. The ability of fire to spread rapidly when there is flammable material can cause losses to property (Ramli, 2010a).

The risk of fire in the bamboo making process can occur from the spread of fire in the combustion system in the fire stove, and the possibility of the fire to be easily spread is because many materials and bamboo handicrafts around it are flammable. This is in line with previous research conducted by Karuniawati (2018), stating that fires at a plywood factory occurs due to popping sounds and bursts of oil from HPV pipes. Around the machine and inside the machine is a flammable plywood material. Air and dust around the workplaceamay also cause fire. If the conditions become more uncontrollable, a small spark can cause a fire.

Smoke in the combustion process occurs because of an incomplete combustion process. Smoke is an unexpected side effect of fire. If an object burns and the oxygen level in the area is sufficient, the combustion will not emit smoke. Furthermore, the existing smoke can cause respiratory problems. When combustion occurs, the smoke that is formed will expel oxygen from the room so that it becomes tight. This condition causes a lack of oxygen and smoke to enter the lungs (Ramli, 2010a; Ramdan, 2013). Aini's (2016) research shows that smoke is one of the identified potential chemical hazards that can be exposed to firefighters. It is stated that smoke due to combustion can causerespiratory problems, even when the workers wear a mask as personal protective equipment.

\section{Physical Hazards}

Physical hazards are factors at the workplace that can affect physical labor activities, including work climate, vibration, microwaves, ultraviolet radiation, statistical magnetic field radiation, air pressure, and lighting (Ministry of Manpower of Republic of Indonesia, 2018). Physical hazards are included in the category of hazards that pose a risk of long-term impacts on health (International Labor Organization, 2013). Potential physical hazards which are identified in each bamboo-making process 
is an increase in sawing noise and heat from the burning process.

Noise will cause hearing loss if it exceeds the Threshold Value, which is $85 \mathrm{~dB}$. Kamila (2018) research shows that there is a difference in pressure at an intensity that exceeds TLV (86-97dB), which damages hearing and has an impact on deafness. Meanwhile, at fire intensity below TLV (82-84dB), it causes psychological and communication problems that cause occupational diseases and accidents. Mukhlish's (2018) research shows that the presence of noise intensity that exceeds TLV in the work environment, especially in the sawmill sector $(90$ dB) can affect the pulse rate of workers before and after working with noise.

In addition to noise hazards, there is also an identification of the danger of vibration in the cutting process. When workers use manual saws on bamboo, the activity will cause vibrations. Workers who use or operate equipment or machinery that cause vibrations are at great risk of exposure to HAVS (Ramdan, 2013).

In addition, there is a potential risk to heat stress. Heat Stress occurs due to the work environment which puts an energy load on the body (Ramdan, 2013). Heat stress can occur if the temperature in the environment is more than TLV. The Temperature Threshold Value in the work environment is determined based on the type of work; light workload should notexceed $30.0 \mathrm{oC}$, medium workload should not exceed $26.7 \mathrm{oC}$, and heavy workloadshould not exceed $25.0 \mathrm{oC}$. Moreover, Mustofani (2019) researchshows the average climate in the warehouse for the fabrication area exceeds TLV $\left(28.4^{\circ} \mathrm{C}\right)$. Physical work carried out is included in the category of moderate workload $(53.3 \%)$ and experiences an increase in light level work $(50 \%)$. The results show that if the working temperature in the work environment exceeds the TLV, it is possible for workers to experience fatigue.

\section{Risk Analysis and Evaluation}

Risk analysis is the systematic use of available information to ensure any possible events which can occur and any possible impacts they may cause. Meanwhile, risk evaluation is to determine risk priorities by assessing risks with defined criteria that can cause potentially dangerous risks (Australian Standard/New Zealand Standards, 2004).

The first step in conducting a risk analysis is to assess the likelihood of a hazard occurring. Of the
22 identified potential hazards, an assessment of the likelihood of hazards is carried out by looking at how often the hazards are likely to occur and seeing how big the impact is when these hazards occur. The assessment is determined by looking at each predetermined criterion.

Identified mechanical hazards are the use of tools such as saws, machetes, raut knives, in the process of making bamboo woven. The risk that occurs is being cut and incised by tools used. This risk has a likelihood value of 3 . Cut and incised wounds are different wounds, and require different treatment depending on the condition of the wound itself. Cut requires emergency medical attention, while incisions can be treated on their own.

Meanwhile, burns due to hot water or contact with hot equipment have a probability value of 3 . The craftsmen accidentally get splashed by hot water when the bamboo strands are put into the boiling water. When lifting or preparing hot equipment, occasionally hands or other limbs come into contact with the equipment. Burns that occur can be minor or severe depending on the existing conditions. However, any form of wound requires medical treatment, so the value of the consequences is 3 . This risk is included in the category of moderate risk, and this burn should be done in the same way as control at moderate risk.

The risk of being incised and punctured can also come from the bamboo material itself. The bamboo material has a very sharp material when it becomes part of the bamboo which is called hinis. This incised or punctured wound has a likelihood value of 5 , which means it is very likely or almost certain to occur on all occasions. This is because in every work process the craftsmenare directly working withthis bamboo material. The consequence value is 2 , which means minor injuries need first aid. Based on the result of multiplying the likelihood and consequences, these cut and incised wounds have a moderate risk. Based on this, the treatment for the risk of being cut and punctured by bamboo material is the same as the treatment for moderate risk.

Another point to note is webbing. Most of the webbing activities are done in awkward positions, which causes complaints to the skeletal muscles. Based on the estimation of the likelihood, this risk has a value of 4 , which means that this risk may or may not be something to happen. Meanwhile, the consequence value is 3 asthis can cause damage to the injured muscle and requires maintenance, and the muscle will work on it. Based on the result of 
the multiplication of likelihood and risk, this risk is included in the high-risk category that requires priority.

Moreover, the dust that is produced from the cutting process of bamboo along with the bamboo "lugut" hairs of bamboo can pose a risk of respiratory problems and itching of the skin. This risk has a probability value of 4 , which means that, this risk is maybe or not something strange happens because workers must come in contact with bamboo material and bamboo dust even though they are not in the cutting process. The bamboo material itself has dust, especially bamboo feathers that can make 'tingling' or itching. As for the risk consequence value, it is known to have a consequence value of 2 , namely minor injuries only need first

aid. Based on the results of the multiplication of likelihoods and consequences, this risk is included in the moderate risk where the work can be continued or if possible, the risk is first reduced with appropriate controls.

Moreover, the use of "naphtol" dye has quite a dangerous impact. This risk has a likelihood 3 value, which means that the risk can occur considering the fact that the use of dyes is sometimes carried out if the order has been determined. This risk has a consequence value also 3 , where the impact of ingestion and contact with the skin and eyes causes irritation to the eyes and skin diseases, which require very serious medical treatment. This risk is also included in the moderate category, meaning that If this risk happens, work can be continued or if possible, the risk can be reduced first with appropriate controls.

Fire and smoke from furnace combustion processes are other chemical hazards, which can pose different risks. The likelihood value of fire is 2 , which means that fire causing a fire is something that has never happened before or is unlikely to occur. This is because the use of fire in the furnace system is quite controlled. Meanwhile. smoke has a probability value of 4 , the smoke disturbance caused by the combustion process is something that may or may not happen, depending on the amount of smoke produced when the combustion process in the furnace occurs. The loss value for the risk of fire is related to the fatal impact of fire. If this condition occurs, more than one person can be affected, and the losses are very large and the impact is so wide that all activities can be stopped. So, the level of risk from fire is included in the moderate risk category. $\mathrm{M}$ eanwhile, the likelihood of the occurrence is small, so the work can be continued or if possible, the risk is reduced first with appropriate controls.

In addition, noise causes hearing loss if it exceeds the $85 \mathrm{~dB}$ Threshold Value. This risk has a likelihood value of 3 and a consequence value of 3. Risk of hearing loss may or may not happen. Noise can have a serious impact, which requires special medical care if the noise level exceeds the TLV,so the level of noise risk is included in the moderate category. The consequence score of Hazard Analysis Verification (HAV) due to vibration is 3 because in the event of HAV it may require serious treatment. Meanwhile, the likelihood score is 2 because HAV may not be common. Therefore, the risk of developing HAV is included in the moderate risk category. Meanwhile, for heat stress, the likelihood of the risk of hot temperatures in the work environment is 3 because it is possible to occur and the consequence value is 2 because the impact is not too significant, giventhat the temperature level generated is subjectively still within the normal temperature range.

\section{Risk Control}

Risk control is a part of risk management policies, standards, procedures and physical changes to eliminate risk adverse events. Risk control is a systematic hierarchy that must be carried out sequentially until the risk is at a harmless (safe) condition. The hierarchy consists of stages of elimination, substitution, technical engineering, administrative and use of personal protective equipment (Australian Standard/New Zealand Standards, 2004).

\section{High-risk Control}

A high riskis a risk that must be prioritized to control. Risks that are included in the high-risk level are derived from ergonomic hazards. The results of field observations have not been carried out to control the risk of ergonomic hazards in the bamboo woven making process. The principle of ergonomics is to match the job for workers. Therefore, the control that can be done is to arrange work and work areas to suit the needs of workers, so it is not workers who adjust to their work (International Labor Organization, 2013).

The ergonomic hazards identified in the process of making bamboo wovens are that the craftsmen take too long in an awkward position when making bamboo wovens, namely sitting on the floor, and 
standing or squatting with the body and head bent. In addition, craftsmen use their hands with repetitive motions, especially when weaving.

The ideal work attitude will occur when workers work with a few static muscles, usehands easily and naturally while doing work, maintain little muscular effory, and have the dynamic work posture, not a tense one. If the job is done in a sitting position, workers should pay attention to a good position, namely 90 degrees of knee flexion, 90 degrees of body-thigh flexion, and the rotation of the back of the pelvis greater than or equal to 30 degrees. Likewise, the standing posture must consider ergonomic principles. When compared to a standing position, the sitting position is better because sitting requires less energy, which reduces the burden on the leg muscles (Tarwaka, 2010).

Mindayani's (2018) research focuses on the interventions to improve work facilities to reduce musculoskeletal complaints. The intervention carried out is to provide a work chair that pays attention to dimensions according to the anthropocentric data of hand embroidery craftsmen technique. This is successful to reduce the number of craftsmen who experience musculoskeletal complaints. This finding is in line with the results of Rosanti and Wulandari's(2016) study regarding work chair repair interventions for sewing craftsmen is It is known that these interventions cause differences in musculoskeletal complaints before and after the intervention.

Most of the stages of the process of making bamboo wovens are sitting on the floor. Based on this, the recommended control is the substitution approach, which is changing the work position from sitting on the floor to sitting on an ergonomically appropriate table. The engineering approach is done by providing appropriate work desks and chairs. Meanwhile, the administrative approach is by stretching every 2 hours.

\section{Moderate Risk Control}

The level of risk in the moderate risk category is not prioritized, but actions must be taken immediately. The moderate risk category is a nonemergency condition (Australian Standard/New Zealand Standards, 2004)). The hazards identified at the moderate risk level are mechanical, chemical, and physical hazards. Mechanical hazards come from tools used (saws, machetes and raut knife), hot materials and tools, and also from the bamboo material itself. The craftsmen have carried out minimal control to reduce the risk of mechanical hazards, namely by wearing gloves, and black duct tape on their hands while working, but the frequency of using PPE is still in the rare category, so that the control recommendations are consistent with the use of PPE.

Personal protective equipment (PPE) is a control that must be a last resort, and must always be used in combination with other control methods. Personal protective equipment is often the easiest alternative of controls to implement, but it is usually the least effective. The level of compliance with the use of personal protective equipment is influenced by many factors, one of which is workers's perceptions of risks and hazards. The results of Shobib (2013) show that the variable related to adherence to the use of PPE is risk perception ( $\mathrm{p}$-value $=0.034$ ). Knowledge of the danger and risks of bamboo weaving craftsmen are still lacking, assuming that scratching of bamboo splinters is a common thing.

Meanwhile, chemical hazards originating from bamboo dust, dyes, fire and smoke come from the combustion system. Chemical hazard control can be carried out without contact with sources of chemical hazards. Maharani's (2020) research explains that one way to control wood dust is by watering dusty work areas so that flying dust can be reduced. This method can be done, namely by making the sawed bamboo wet so that the water in the bamboo will keep the dust from the sawing process from scattering. Also, the security can be done by using personal protection with a special wood dust respirator and face shield. This is in line with Putri's (2019) research, suggesting that chemical hazards come in the form of dust particles and dust masks.

Furthermore, the noise comes from the bamboo sawing process. There are no measurement results for the noise level at the time of sawing the bamboo, but workers can still communicate clearly when the saw is running. Therefore, it is possible that the noise level is still below TLV. However, when the noise exceeds $85 \mathrm{~dB}$ with an exposure duration of \pm 8 hours, there is a risk of hearing loss. So if that happens, the recommendation for control is to use ear plugs to reduce noise levels (Ramdan, 2013).

Mayasari's (2017) research states that the use of earplugs or earmuffscan sound up to a certain frequency. Earplugs and earmuffs can make reduce the intensity by $10-40 \mathrm{~dB}$. This is in line with Ramdan (2013), who explains that the use of the earplug type APT can reduce the noise to $40-50 \mathrm{~dB}$ 
(A), while the earplug type APT can only reduce up to $30 \mathrm{~dB}(\mathrm{~A})$.

\section{Low-risk Control}

Low-risk level can be simply handled with the applicable routine procedures. Included in this category are physical hazards, namely hot temperatures in the workplace originating from the combustion process. Hot and cold temperatures at the workplace are influenced by the personal factors and environmental factors. Personal factors consist of clothing used and metabolic heat. Meanwhile, the environmental factors include air temperature, radiation temperature, air velocity, and humidity. The combination of these four factors results in the air temperature in the work environment. If one of them increases or decreases, it will change the air temperature in the environment. One of the changes in temperature in the bamboo weaving workplace is due to the combustion process which increases the heat to the room temperature (Ramdan, 2013). Unfortunately, there is no measurement of the level of heat in the bamboo weaving place. However, if the ventilation is done properly, it will help reduce the risk of heat stress hazards due to the temperature of the work environment.

\section{CONCLUSION}

Based on the results of the risk assessment, it can be concluded that in the process of making bamboo woven there are 22 identified potential hazards, namely 2 types of physical hazards, 5 types of chemical hazards, 6 types of ergonomic hazards, and 9 types of mechanical hazards. Of these hazards, 1 is alow-risk, 14 re medium risk, and 7 are high-risk. Types of hazards at a high-risk rating that need immediate control are ergonomic hazards.

\section{ACKNOWLEDGEMENTS}

This research will not run smoothly without the help of many parties. The researchers would like to thank the Ministry of Research and Technology/ National Research and Innovation Agency for the opportunity to get research grants, STIKes Respati Tasikmalaya which always support all tridharma activities, and owners and craftsmen of woven bamboo crafts who always supply crafts to the Rajapolah handicraft center.

\section{REFERENCES}

Aini, A. N. (2016) ‘Analisis Risiko Kerja Dan Upaya Pengendalian Bahaya Pada Petugas Pemadam Kebakaran Di Dinas Pemadam Kebakaran Kota Semarang', Jurnal Kesehatan Masyarakat, 4(1), pp. 277-283.

Ardam, K. A. Y. (2015) 'Hubungan paparan debu dan lama paparan dengan gangguan faal paru pekerja overhaul power plant', The Indonesian Journal OfOccupational Safety and Health, 4(2), pp. 155-166.

Asriyati (2019) 'Faktor-Faktor Yang Mempengaruhi Pembuatan Anyaman Bambu (Lambar) Di Desa Tanjungsari Kecamatan Petanahan Kabupaten Kebumen', Jurnal Riset Agribisnis dan Peternakan, 4(1), pp. 1-8.

Australian Standard/New Zealand Standards (2004) Handbook: Risk Management Guidelines Companion to AS/NZS 4360: 2004. Australia: Standards Australia/Standards New Zealand Australia.

Badan Penyelenggara Jaminan Sosial Ketenagakerjaan (2019) Kecelakaan Kerja Cenderung Meningkat, Kesehatan Kerja Badan Penyelenggara Jaminan Sosial membayar santunan Rp 1,2 Triliun. Jakarta: Badan Penyelenggara Jaminan Sosial Ketenagakerjaan.

Central Bureau of Statistics of Tasikmalaya Regency (2019) Kabupaten Rajapolah Dalam Angka 2019. Tasikmalaya: Central Bureau of Statistics of Tasikmalaya Regency.

Fani, H. (2013) 'Safety Risk Assessment of Mechanical Hazards on Wood Furniture Workers In Informal Industry" Indah Jati Furniture"', in International Meeting of Public Health (IMOPH). Depok, pp. 1-14.

International Labor Organization (2013) Keselamatan dan Kesehatan Kerja Sarana untuk Produktivitas. Jakarta: International Labor Organization.

Jalajuwita, R. N. and Paskarini, I. (2015) 'Hubungan posisi kerja dengan keluhan muskuloskeletal pada unit pengelasan PT. X Bekasi', The Indonesian Journal OfOccupational Safety and Health, 4(1), pp. 33-42.

Kamila, E. Z. (2018) Gambaran Kebisingan dan Potensi Bahayanya Serta Upaya Pengendalian pada Unit Pengolahan Teh di PT Candi Loka Kabupaten Ngawi Tahun 2018. Undergraduate Thesisi. Surabaya :Department of Environmental Health, Poltekes Surabaya.

Karuniawati, E. Y. (2018) 'Analisis Kejadian Kebakaran dengan Metode "Loss Causation 
Model" pada Sebuah Pabrik Kayu Lapis di Pacitan', Jurnal Kesehatan Masyarakat, 6(4), pp. 286-291.

Ma'rufi, I. (2017) 'Efek Pajanan Debu Kayu terhadap Gangguan Faal Paru', MPI (Media Pharmaceutica Indonesiana), 1(1), pp. 45-52.

Maharani, F. T. (2020) 'Pengendalian Debu Kayu di PT.X', Indonesian Jurnal of Health Development, 2(1), pp. 1-14.

Mayasari, D. (2017) 'Pencegahan Noise Induced Hearing Loss pada Pekerja Akibat Kebisingan', Jurnal Agromedicine, 4(2), pp. 354-360.

Mindayani, S. (2018) 'Perbaikan Fasilitas Kerja Untuk Mengurangi Keluhan Muskuloskeletal', Jurnal Endurance, 3(2), pp. 313-324.

Ministry of Manpower of Republic of Indonesia (2018) Nomor 05 Tahun 2018 tentang Keselamatan dan Kesehatan Kerja di Lingkungan Kerja. Jakarta: Ministry of Manpower of Republic of Indonesia.

Muhammad, K. (2015) Pertolongan Pertama. Jakarta: PT Gramedia.

Mukhlish, W. I. N. (2018) 'Pengaruh Kebisingan Terhadap Tekanan Darah dan Nadi pada Pekerja Pabrik Kayu PT. Muroco Jember', Jurnal Kesehatan Lingkungan Indonesia, 17(2), pp. 112-118.

Murti, K. A. H. (2018) 'Kerajinan Anyam Bambu di Sanggar Hamid Jaya Desa Gintangan Kecamatan Rogojampi Kabupaten Banyuwangi', Jurnal Seni Rupa, 6(1), pp. 634-644.

Mustofani (2019) 'Hubungan Antara Iklim Kerja dan Beban Kerja dengan Kelelahan Kerja pada Pekerja di Gudang 5 Area Fabrikasi PT. Bangun Sarana Baja', The Indonesian Journal Of Occupational Safety and Health, 8(2), pp. 150-157.

Prabawati, M. N. (2016) 'Etnomatematika masyarakat pengrajin anyaman rajapolah kabupaten tasikmalaya', Infinity Journal, 5(1), pp. 25-31.

President of Republic of Indonesia (2009) UndangUndang Nomor 36 Tahun 2009 Tentang Kesehatan. Jakarta: President of Republic of Indonesia.

Putri, R. N. (2019) 'Permodelan Risiko Bahaya Kimia Guna Menentukan Pengendalian Bahaya
Kesehatan', Journal of Industrial Hygiene and Occupational Health, 4(1), pp. 80-97.

Ramdan, I. M. (2013) Higiene Industri. Yogyakarta: Bimotry.

Ramli, S. (2010a) Manajemen Kebakaran. 1st edn. Jakarta: PT Dian Rakyat.

Ramli, S. (2010b) Sistem Manajemen Kesehatan dan Keselamatan Kerja OHSAS 18001. Jakarta: Dian Rakyat.

Rosanti, E. and Wulandari, D. (2016) 'Pengaruh Perbaikan Kursi Kerja Terhadap Keluhan Muskuloskeletal pada Pekerjaan Menjahit di Desa X', Journal of Industrial Hygiene and Occupational Health, 1(1), pp. 23-38.

Santosa, Z. (2019) Mengatasi Luka Gores dan Luka Bakar. Yogyakarta: CV Alaf Media.

Sentra Informasi Keracunan Nasional (2011) 1-Napthol. Jakarta: National Agency of Drug and Food Control.

Setiadi, A. (2009) Sifat Kimia Beberapa Jenis Bambu pada Empat Tipe Ikatan Pembuluh. Thesis. Bogor: Faculty of Forestry, Institut Pertanian Bogor.

Shobib, M. N. (2013) Hubungan Antara Pengetahuan dan Sikap dengan Praktik Penggunaan APD pada Petani Pengguna Pestisida di Desa Curut Kecamatan Penawangan Kab. Grobogan Tahun 2013. Undergraduate Thesis. Semarang: Faculty of Health Science, Universitas Dian Nuswantoro.

Stamatis, D. (2014) 'Preliminary Hazard Analysis (PHA)', in Introduction to Risk and Failures. Boca Raton: CRC Press.

Suma'mur, P. K. (2009) Higiene Perusahaan dan Kesehatan Kerja (HIPERKES). Jakarta: Sagung Seto.

Tarwaka (2010) Ergonomi Industri Dasar-dasar Pengetahuan Ergonomi dan Aplikasi di Tempat Kerja. Surakarta: Harapan Press.

Widyawati, V. (2019) Jadi Dokter Keluarga di Rumah Sendiri. Yogyakarta: Laksana.

Yani, F. (2020) 'Hubungan Masa Kerja Dan Lama Kerja Dengan Nyeri Leher Pada Pembatik Di Sentra Batik Giriloyo', The Indonesian Journal of Ergonomic, 6(1), pp. 31-36. 